Article - Agriculture, Agribusiness and Biotechnology

\title{
The Effect of Temperature and Growth Regulators on Callus Induction in Watermelon Anthers
}

\author{
Carla Maria de Jesus Silva ${ }^{1 *}$ \\ https://orcid.org/0000-0002-9825-2235 \\ Rita de Cássia Souza Dias ${ }^{2}$ \\ https://orcid.org/0000-0002-5527-3693

\section{Natoniel Franklin de Melo $^{2^{*}}$ \\ https://orcid.org/0000-0001-6888-4090}

${ }^{1}$ Feira de Santana State University, Postgraduate Program in Plant Genetic Resources, Feira de Santana, Bahia, Brazil; 'Brazilian Agricultural Research Corporation, Embrapa Semiárido, Biotechnology Laboratory, Petrolina, Pernambuco, Brazil.

Editor-in-Chief: Paulo Vitor Farago

Associate Editor: Adriel Ferreira da Fonseca

Received: 2018.09.18; Accepted: 2020.10.07.

*Correspondence: carlamjs@yahoo.com.br; Tel.: +87-3866-3701 (C.M.J.S.).

\section{HIGHLIGHTS}

- Callogenesis was induced from watermelon anthers

- The auxin 2,4-D at 2.0 and $5.0 \mu \mathrm{M}$ concentrations induced callus formation.

- Anthers' responses to the pre-treatment at $4{ }^{\circ} \mathrm{C}$ varied according to the watermelon genotype.

\begin{abstract}
Callus induction is one of the pathways required for haploid plant regeneration through anther culture. Pollen viability, as well as the effect of growth regulators and cold pretreatment on anthers of two watermelon lines (Smile and Sugar Baby) to induce callus formation were herein evaluated. Pollen viability was estimated through the staining technique using $2 \%$ acetic carmine. Male flower buds were collected and disinfested to allow removal anthers. These anthers were placed on Murashige and Skoog medium, which was supplemented with 2,4-dichlorophenoxyacetic (2,4-D) at $0.0,0.5,1.0,2.0$ or $5.0 \mu \mathrm{M}$ or with 6benzylaminopurine at $0.0,0.5,1.0,1.5$, or $2.0 \mu \mathrm{M}$, in combination with $2.0 \mu \mathrm{M}$ of 2,4-dichlorophenoxyacetic. Anthers were pretreated at $4{ }^{\circ} \mathrm{C}$, for two days and then placed in vitro. Both watermelon lines provided high pollen viability rates (from 93 to $98 \%$ ). The 2.0 and $5.0 \mu \mathrm{M}$ concentrations of 2,4-D stimulated higher friable callus formation. The optimal concentration of 2,4-D was estimated at $3.78 \mu \mathrm{M}$ and $4.17 \mu \mathrm{M}$, which had callus induction rates of $64 \%$ and $52 \%$, respectively. The combination of $2.0 \mu \mathrm{M}$ of $2,4-\mathrm{D}$ and 6 benzylaminopurine did not lead to increased anther response to callus induction. The pre-treatment applied to flower buds at $4{ }^{\circ} \mathrm{C}$ enabled callus induction and the anther response to callus induction was genotypedependent.
\end{abstract}

Keywords: anther callogenesis; Citrullus lanatus; plant growth regulator; pollen viability. 


\section{INTRODUCTION}

Watermelons [Citrullus lanatus var. lanatus (Thunb.) Matsum \& Nakai] belong to the Cucurbitaceae family, and are distributed worldwide [28,15]. China was the world's largest watermelon producer in 2016, followed by Turkey, Iran and Brazil. Together these countries produced approximately $76 \%$ of the total global production [6].

Watermelon fruits are a source of $\mathrm{C}$ vitamin and $\mathrm{B}$ complex, as well as minerals, such as calcium, phosphorus and iron. The water volume in the fruit reaches $90 \%$ of the total fruit composition. Watermelon fruits have hydrating and diuretic properties, besides their ability to eliminate digestive system residues and to work as laxative. It has abundant lycopene (antioxidant), which gives the red color to the fruit, and is an excellent source of citrulline (amino acid). The yellow flesh cultivars provide $\beta$-carotene (pro-vitamin A) and xanthophylls [5].

Although many years (10-12) are required to produce homozygous lines through conventional watermelon breeding techniques, faster and more effective techniques are available in vitro, such as "haploidy techniques". The use of this technique can produce $100 \%$ pure homozygous lines by using haploid chromosomes and then duplicating these chromosomes with colchicine. Thus, the homozygote production process can be reduced to one or two years compared to 10 years or more [4]. Among the techniques in vitro, the culture of anthers allows the production of haploid plants that can be used to produce homozygous double-haploid lines, after chromosome duplication [8].

Several methods have been used to induce haploid Cucurbitaceae plants, such as the use of irradiated pollen in melons [25] and watermelons [12,22], as well as the use of gynogenesis (ova and ovaries cultured in vitro) and androgenesis (microspores and anthers cultured in vitro) [7]. One of the routes that can be followed in androgenesis lines for callus proliferation and formation [9], is via embryogenesis or organogenesis to form a new plant [21, 8]. Previous studies regarding callus induction focused on efficient plant regeneration using different explant types in cucumbers $[2,10]$ and pumpkins [20].

Pollen viability studies are important and necessary for plant breeding programs [26], since plants carrying non-viable pollen result in sterile plants and in lower grain yield [27]. Therefore, estimating pollen viability is potentially useful for the androgenesis process, since the use of anthers with viable pollen grains may enable the formation of normal individuals. Several colorimetric methods can be used to estimate pollen grain viability, including staining with 2,3,5-triphenyltetrazolium chloride (TTC), Alexander's stain, acetic carmine, Lugol solution and Sudan IV [17]. However, few studies have been conducted on pollen viability in watermelon.

The use of growth regulators is another factor that must be considered when using anther culture in many plant species, such as watermelon. Abdollahi and coauthors selected watermelon cultivars (Charleston Gray and Crimson Sweet) to investigate the use of phytohormones on anthers in order to produce calluses and embryos to regenerate double-haploid plants through anther culture. Ashok Kumar and coauthors obtained calluses, embryos and, consequently, haploid plants by using different 2,4dichlorophenoxyacetic acid (2,4-D), 6-benzylaminopurine (BAP), kinetin (KIN) and thidiazuron (TDZ) concentrations, as well as the combination between these regulators in cucumber (Cucumis sativus). Song and coauthors also recorded successful androgenesis in cucumber plants, as calluses and embryos were obtained along with regenerating double-haploid plants by using 2,4-D, BAP and KIN [24].

The pretreatment of anthers at high and low temperatures is another factor capable of improving anther tissue. According to Germaná (2011), the cold pre-treatment at $4{ }^{\circ} \mathrm{C}$ for $2-3$ weeks has been routinely used in the anther culture of many species and is genotype-dependent. Studies conducted with plants belonging to the Cucurbitaceae family had good callus induction results in cucumber $(47.76 \%$ in 'Calypso' and $54.43 \%$ in 'Green Long') [3,24] and in 'Crimson Sweet' watermelon (45.00\%), when of applying the pretreatment to anthers at $4{ }^{\circ} \mathrm{C}$ for two days [1].

Since studies on anther culture in watermelon remain scarce in Brazil, the aim of the current study was to estimate pollen viability, as well as to investigate the responses of different watermelon genotypes to callus formation in anther tissues through the use of growth regulators and different temperatures. 


\section{MATERIAL AND METHODS}

\section{Plant material}

Materials used in the present study comprised two watermelon lines (Smile and Sugar Baby) from the Cucurbit Germplasm Active Bank for the Brazilian Northeastern Region (BGCIA- Banco Ativo de Germoplasma de Cucurbitáceas para o Nordeste Brasileiro), which belongs to Embrapa Semi-arid.

\section{Pollen viability}

Pollen analyses were based on the procedure previously described [11]. Three flower buds from each line (Smile and Sugar Baby) were collected in the morning, before anthesis, after 30 cultivation days in the field. Flower buds were directly fixed in Carnoy solution at the ratio 3:1 (ethanol: glacial acetic acid, v/v), where they were kept for 2 to 24 hours at room temperature. Next, they were stored at $-20{ }^{\circ} \mathrm{C}$, until analysis. Subsequently, a stereomicroscope was used to help remove the anthers in order to collect pollen grains, which were distributed in glass slides for staining purposes.

Pollen viability of the lines was estimated by using $2 \%$ acetic carmine staining and by counting pollen grains in five random points of the slide. Two hundred (200) pollen grains from three anthers of each floral bud were evaluated. Unstained pollen grains presenting smaller size and wrinkled cytoplasmic wall were considered non-viable. The Dino Capture 2.0 software was used to determine pollen grain diameter by measuring the longest transverse length of the grain.

\section{Collection, disinfestation and anther culture conditions}

Male floral buds ( 3 to $5 \mathrm{~mm}$ long) of both lines (Smile and Sugar Baby) were collected in the morning, before anthesis, after 30 cultivation days in the field. Flower buds were washed in running water for approximately 5 minutes in the laboratory, disinfested in a laminar flow cabinet with $70 \%$ alcohol for 1 min and with $20 \%$ sodium hypochlorite (v/v) for $15 \mathrm{~min}$; this procedure was followed by a triple wash in distilled and autoclaved water. After the disinfestation procedure, an incision was made to open the buds and remove the anthers, which were then placed in Petri dishes containing $20 \mathrm{ml}$ of culture medium.

A MS culture medium was used [16] and a was supplemented with $30 \mathrm{~g} \mathrm{~L}^{-1}$ sucrose and $5.0 \mathrm{~g} \mathrm{~L}^{-1}$ agar; the $\mathrm{pH}$ was adjusted to $5.9 \pm 0.1$, and was autoclaved at $120^{\circ} \mathrm{C}$ and $1 \mathrm{~atm}$ for $25 \mathrm{~min}$. Two experiments were conducted using a completely randomized design (CRD) with five repetitions. An experimental unit was a Petri dish containing 12 anthers, totaling five dishes and 60 anthers. The MS medium was supplemented with different concentrations of 2,4-D, which adopted the double factorial arrangement $(2 \times 5)$ of two lines deriving from 'Smile' and 'Sugar Baby' $x$ five different 2,4-D concentrations $(0.0,0.5,1.0,2.0$ and $5.0 \mu \mathrm{M}$ ), totaling 10 treatments. The option made for these concentrations was based on the adaption of reports by Ashok Kumar and coauthors and Abdollahi and coauthors [1]. The concentration of choice in the second experiment was $2.0 \mu \mathrm{M}$ because it effectively induced callus in the first experiment, which were very close to that recorded for $5.0 \mu \mathrm{M}$. The last experiment adopted the triple factorial arrangement $(2 \times 2 \times 5)$ with two lines deriving from 'Smile' and 'Sugar Baby' $x$ presence and absence of cold pre-treatment $x$ five BAP concentrations $(0.0,0.5,1.0,1.5$ and $2.0 \mu \mathrm{M})$, totaling 20 treatments. The medium of all treatments was added with $2.0 \mu \mathrm{M}$ of $2,4-\mathrm{D}$.

The collected flower buds subjected to cold pre-treatment were arranged on a Petri dish, which was placed on filter paper moistened with autoclaved distilled water, and kept in refrigerator at $4{ }^{\circ} \mathrm{C}$ for two days. They were then inoculated in the culture medium and incubated in a growth room at $23 \pm 2{ }^{\circ} \mathrm{C}$ for four weeks. Subsequently, they were subjected to 16-hour light/dark photoperiod (light intensity $40 \mathrm{\mu mol}^{-2} \mathrm{~s}^{-1}$ ) under fluorescent lamps.

\section{Evaluations and statistical analyses}

The analysis applied to the pollen viability estimates evaluated the percentage of viable pollen grains, as well as the diameters of viable and non-viable pollen grains. Data were subjected to analysis of variance (ANOVA) and means were compared through the Tukey test, at $5 \%$ significance level, using $R$ software version 3.3.2 [20].

Evaluations were performed after four incubation weeks. The percentage of anthers forming callus was evaluated, and a rating scale was attributed to the percentage of oxidized anthers $(0=0 \% ; 1=1$ to $30 \%$; 
$2=31$ to $60 \% ; 3=61$ to $90 \%$; and $4=91$ to $100 \%$ ). The color of the oxidized anthers was assessed based on the plant tissue color [18].

Data resulting from the first experiment were subjected to analysis of variance (ANOVA). Mean genotype values were compared to each other using Tukey's test at the $5 \%$ significance level. Mean genotype values resulting from treatments with different growth regulator concentrations were compared through regression analysis. Data in the second experiment were not normally distributed. Thus, they were analyzed through descriptive statistics by adopting variables such as callus induction frequency \pm standard error. All analyses were performed using R statistical software version 3.3.2 [19].

\section{RESULTS AND DISCUSSION}

\section{Pollen viability}

Pollen viability estimates and grain diameter differences between the two watermelon lines are shown in Table 1. Both lines showed mostly viable (stained) pollen grains (Figure 1A), whose estimated viability was higher than $93 \%$. These results indicate high fertility, since high pollen viability is correlated with normal and balanced gamete formation in order to assure successful species reproduction [13].

Table 1. Pollen grain viability estimates in two watermelon lines (Citrullus lanatus) based on the staining technique by using $2 \%$ acetic carmine.

\begin{tabular}{cccc}
\hline Lines & ${ }^{*}$ PV & ${ }^{* *}$ VPGD & ${ }^{* * \text { NVPGD }}$ \\
\hline Mean $(\%)$ & $(\mu \mathrm{m})$ & $(\mu \mathrm{m})$ \\
\hline Smile & $93.5 \mathrm{a}$ & $60.41 \mathrm{a}$ & $51.10 \mathrm{a}$ \\
Sugar Baby & $98.0 \mathrm{a}$ & $55.14 \mathrm{~b}$ & $45.22 \mathrm{~b}$
\end{tabular}

Means followed by the same lowercase letters in a column did not statistically differ from each other using Tukey's test at $5 \%$ significance level. * Pollen viability ${ }^{* *}$ Viable pollen grain diameter ${ }^{* * *}$ Non-viable pollen grain diameter.
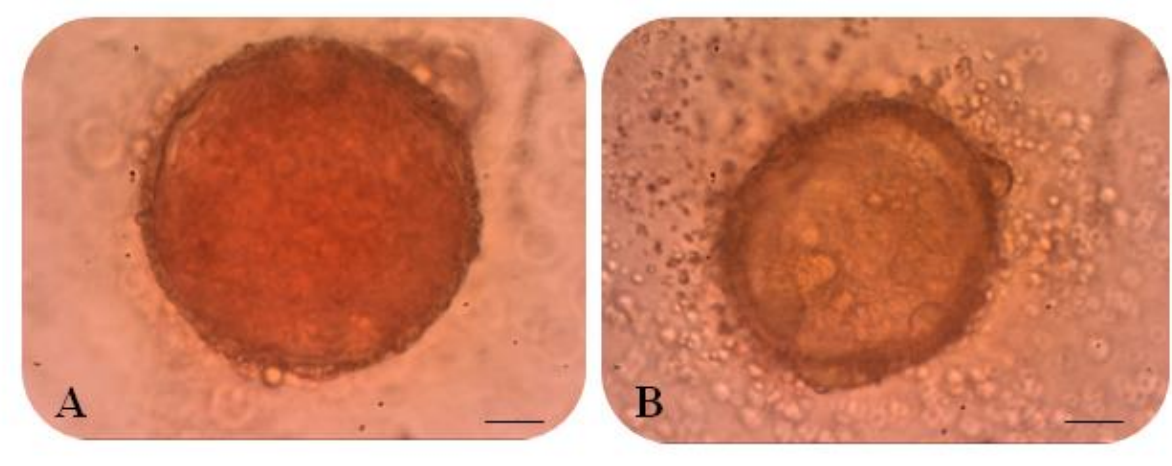

Figure 1. Pollen grains of watermelon lines (Citrullus lanatus) subjected to staining with $2 \%$ acetic carmine. (A) Viable (stained) and (B) non-viable (not stained) pollen grains. Bars represent $=10 \mu \mathrm{m}$

There was significant variation in the size of viable and non-viable pollen grains between the two watermelon lines. 'Smile' produced the largest viable and non-viable pollen grains (Figure 1B; Table 1). These morphological differences may have resulted from variations between the two genotypes that resulted from the parents used to make the lines. According to Zanotto and coauthors variations observed between different genotypes are intrinsic to each accession, mainly when they are used in plant breeding programs, since they involve different genotype crosses and origins. Different varieties of a single species may present strong variability in pollen grain viability [27].

\section{The effect of 2,4-D growth regulator on callus induction based on anthers (experiment 1)}

No interactions were detected between the watermelon genotypes and concentrations (Table 2). However, there was different callus induction responses between 2,4-D regulator concentrations (Figure 2). Anthers inoculated on MS medium supplemented with 2,4-D (0.5, 1.0, 2.0 and 5.0 $\mu \mathrm{M})$ had increased size after 2-3 weeks and developed friable calluses after another 2-3 weeks. The calluses were friable and white translucent (Figures $3 \mathrm{~A}$ to $3 \mathrm{E}$ ). 


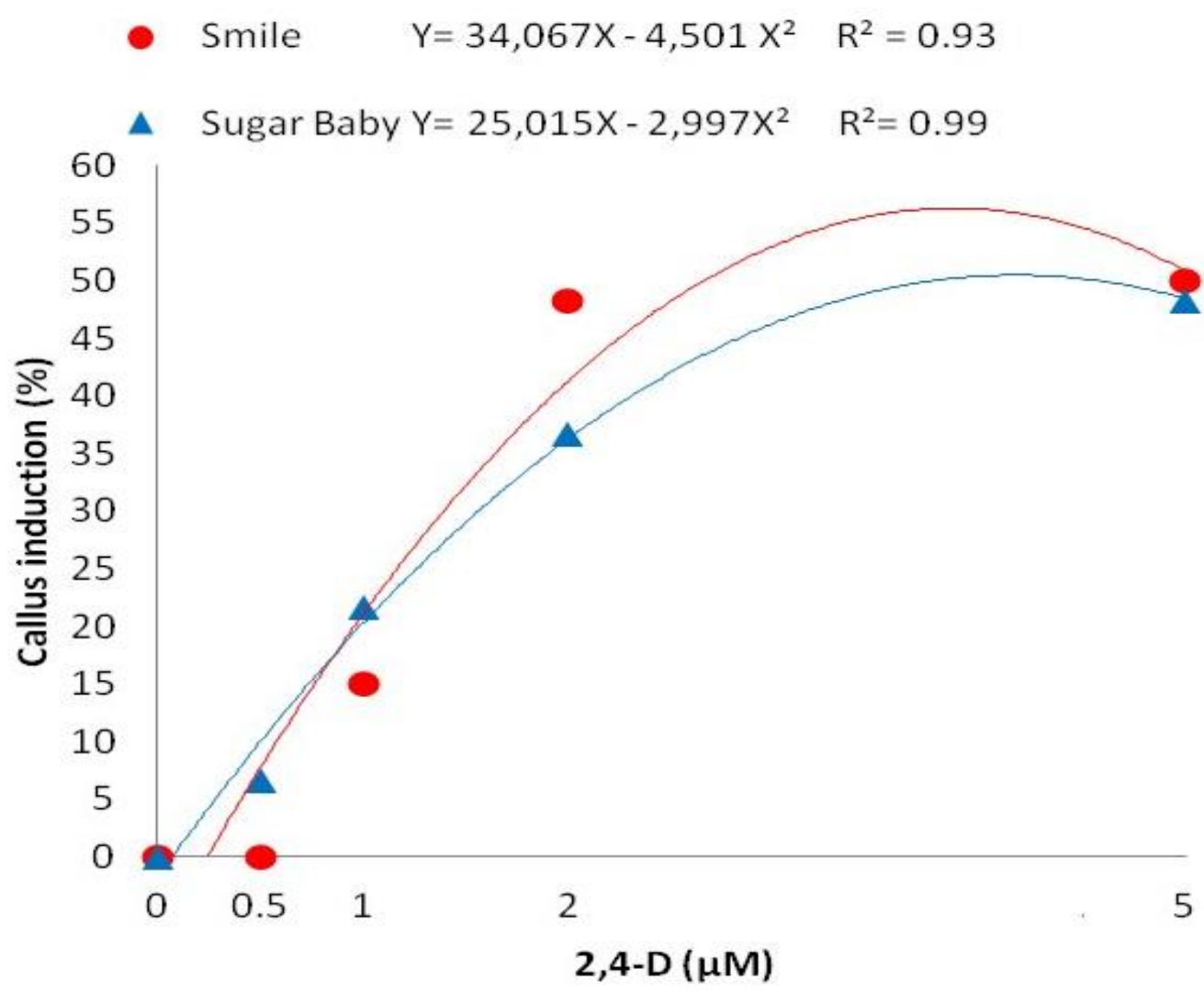

Figure 2. Friable callus induction in watermelon anthers from 'Smile' and 'Sugar Baby', based on different 2,4-D concentrations (Experiment 1). p-value 0.002 was and 0.029 respectively for 'Smile' and 'Sugar Baby'.
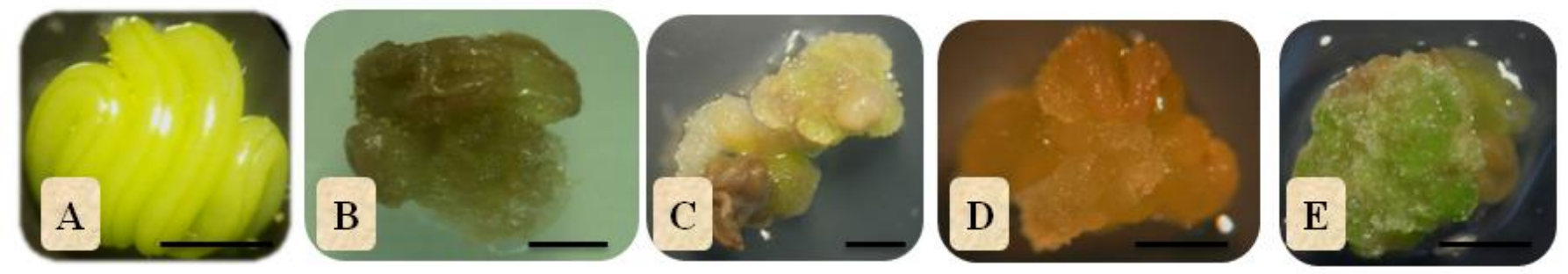

Figure 3. Friable callus induction response in vitro in watermelon anthers (Citrullus lanatus) from 'Smile' and 'Sugar Baby' lines: (A) Anther; (B) and (C) Callus formation derived from anther culture ('Smile' and 'Sugar Baby' lines) grown in medium containing $5.0 \mu \mathrm{M}$ of 2,4-D; (D) and (E) Callus formation derived from anther culture ('Smile' and 'Sugar Baby' lines) grown in medium containing $2.0 \mu \mathrm{M}$ of 2,4D +0.0 of BAP. Bars represent $=10 \mathrm{~mm}$.

The anthers of the two lines grown in MS medium without 2,4-D growth regulator supplementation did not show morphogenic response for four weeks. However, all 2,4-D concentrations stimulated callus induction in 'Sugar Baby' anthers (Figure 2). This line recorded a high oxidation rate for anthers grown in the regulator-free medium and in the medium supplemented with $0.5 \mu \mathrm{M}$ of 2,4-D (Figure 4B). This reaction is undesirable in tissue culture, since it leads to the release and oxidation of phenolic compounds, which darken the explant tissue and inhibit its growth [14]. However, the oxidation resulting from increasing 2,4-D regulator concentrations $(1.0,2.0$ and $5.0 \mu \mathrm{M})$ did not present phytotoxic effects capable of preventing callus formation in the anthers of the two lines (Figures $4 \mathrm{~A}$ and $4 \mathrm{~B}$ ). The $0.5 \mu \mathrm{M}$ concentration of 2,4-D was the only one that did not induce callus formation responses in anthers of the 'Smile' line (Figure 2). Based on the results, callus formation took place only when the 2,4-D regulator was used. This regulator is often used in tissue culture to induce callus formation and to trigger somatic embryogenesis, and is most used at concentrations ranging from 1 to $10 \mathrm{mmol}$ [9]. 
Table 2. Friable callus formation rate in anthers of watermelon lines (Citrullus lanatus) subjected to the 2,4-D growth regulator (Experiment 1)

\begin{tabular}{cccc}
\hline Concentration $(\boldsymbol{\mu M})$ & Inoculated anthers & \multicolumn{2}{c}{ Friable callus induction frequency } \\
$(\%)$
\end{tabular}

${ }^{*}$ Means followed by the same letters did not statistically differ from each other using Tukey's test at $5 \%$ significance level.
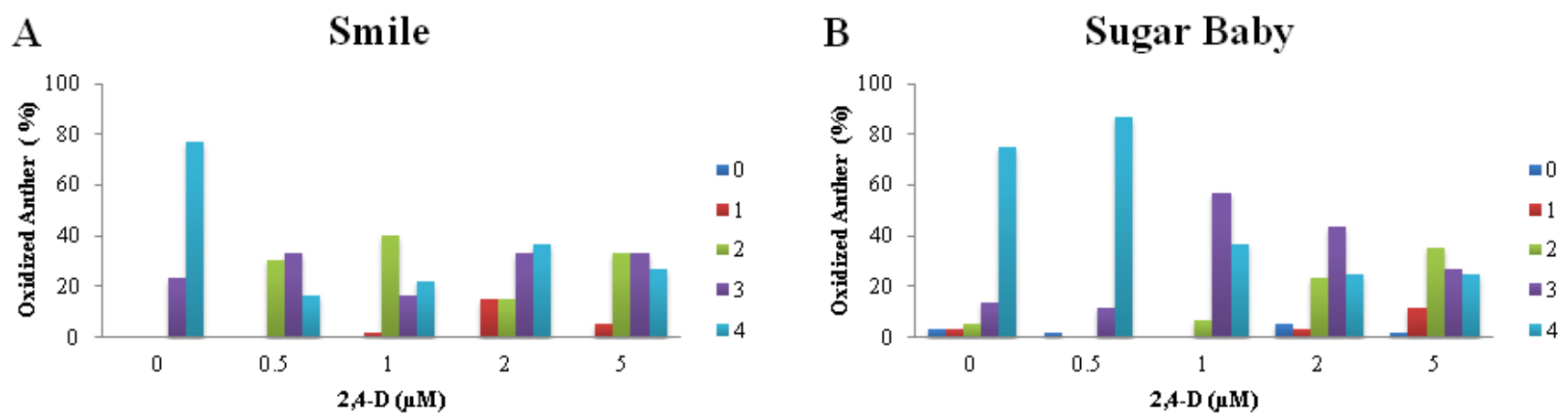

Figure 4. Anther oxidation distribution frequencies in 'Smile' (A) and 'Sugar Baby' (B) watermelon (Citrullus lanatus) lines grown in medium containing different 2,4-D concentrations, with 0) $0 \%$; 1) $1-30 \%$; 2) $31-60 \%$; 3) $61-90 \%$; and 4) $91-100 \%$ of oxidized anthers (Experiment 1 ).

Regression analysis based on different 2,4-D regulator concentrations indicated that quadratic models provided the best fit for both lines with coefficient of determination $\left(R^{2}\right) 93 \%$. The optimal concentration of 2,4-D growth regulator was estimated at 3.78 and $4.17 \mu \mathrm{M}$ for 'Smile' and 'Sugar Baby', respectively; callus formation rate was also estimated at $64 \%$ and $52 \%$, respectively (Figure 2 ). The anthers of the two lines had $15 \%$ and $21 \%$ callus induction for 'Smile' and 'Sugar Baby', respectively, when they were stimulated with $1.0 \mu \mathrm{M}$ of 2,4-D (Figure 2).

The analysis applied to the higher friable callus formation in the anthers of the two watermelon lines, based on 2,4-D regulator concentrations, indicated that the 2.0 and $5.0 \mu \mathrm{M}$ concentrations induced mean callus formation at a rate higher than 35\% (Figure 2). This result was higher than that found by Ashok Kumar and coauthors, who cultivated anthers of two cucumber cultivars in medium supplemented with 2,4$\mathrm{D}$ at concentrations 2.0 and $5.0 \mu \mathrm{M}$ and reported a callus induction rate higher than $25 \%$. Abdollahi and coauthors also found similar results when 'Charleston Gray' watermelon anthers was treated with 2,4-D. They recorded $31.67 \%(2.0 \mu \mathrm{M})$ and $25.0 \%(5.0 \mu \mathrm{M})$ callus induction. According to results in the current study, 2,4-D provided a positive effect on callus induction in the two investigated lines, which confirms the importance of this regulator for callus induction in anther culture of watermelon [24].

\section{The effect of BAP used in combination with 2,4-D and temperature as pre-treatment (experiment 2)}

The effect of using BAP in combination with 2,4-D $(2.0 \mu \mathrm{M})$, and the effect of pre-treatment at $4{ }^{\circ} \mathrm{C}$ for two days for callus induction in watermelon anthers is shown in Table 3. 'Smile' had higher mean anther callus formation rates regardless of pre-treatment at $4{ }^{\circ} \mathrm{C}$ for two days. Genotype is one of the factors capable of influencing pollen response in vitro due to endogenous factors, and different cultivars within a single species can provide different responses [8]. Ashok Kumar and coauthors conducted a study with cucumber plants and found differences in anthers' response to callus induction between cultivars (Calypso and Green Long). Shalaby (2007) evaluated gynogenesis-based haploid induction in vitro in 12 pumpkin genotypes and found different responses to embryo and seedling induction [23]. Furthermore, Golabadi 
and coauthors tested two genotypes in cucumber ovary culture and found significant differences in embryogenesis and callus induction rates [10].

Table 3. The effect of 6-benzylaminopurine (BAP) in combination with $2.0 \mu \mathrm{M}$ of 2,4-dichlorophenoxyacetic (2,4-D) and using low temperature as pre-treatment on the friable callus induction in the anthers of two watermelon lines (Experiment 2).

\begin{tabular}{|c|c|c|c|c|c|}
\hline \multirow[t]{2}{*}{$\begin{array}{c}\text { Growth regulator } \\
(\mu \mathrm{M})\end{array}$} & \multirow[t]{3}{*}{$\begin{array}{l}\text { Inoculated } \\
\text { anthers } \\
\text { (N.) }\end{array}$} & \multicolumn{4}{|c|}{$\begin{array}{l}\text { Friable callus induction frequency }(\%) \\
\text { Mean } \pm \text { standard error } \\
\text { Pre-treatment }(4 \stackrel{\circ}{-} \text { ) }\end{array}$} \\
\hline & & \multicolumn{2}{|c|}{ Smile } & \multicolumn{2}{|c|}{ Sugar Baby } \\
\hline BAP & & Absence & Presence & Absence & Presence \\
\hline 0.0 & 60 & $20.00 \pm 3.33$ & 0.00 & $24.99 \pm 2.64$ & 0.00 \\
\hline 0.5 & 60 & $8.34 \pm 8.33$ & $4.99 \pm 3.33$ & $9.99 \pm 8.08$ & 0.00 \\
\hline 1.0 & 60 & $8.34 \pm 8.33$ & $28.33 \pm 10.07$ & 0.00 & $8.33 \pm 0.21$ \\
\hline 1.5 & 60 & $3.32 \pm 2.04$ & $6.66 \pm 3.12$ & 0.00 & $1.66 \pm 0.19$ \\
\hline 2.0 & 60 & $13.34 \pm 4.25$ & $16.66 \pm 4.46$ & 0.00 & $6.66 \pm 0.19$ \\
\hline Mean & & $10.66 \pm 5.51$ & $11.33 \pm 6.38$ & $6.99 \pm 5.46$ & $3.33 \pm 2.06$ \\
\hline
\end{tabular}

The BAP growth regulator concentrations used in combination with $2.0 \mu \mathrm{M}$ of 2,4-D, were not efficient in increasing the friable callus induction rates in the two evaluated watermelon lines (Table 3 ). This result indicates that the combination between BAP and $2.0 \mu \mathrm{M}$ of 2,4-D was not effective in increasing callus induction in the watermelon lines, since the highest callus induction rates $(20 \%$ and $25 \%)$ were only found when $2.0 \mu \mathrm{M}$ of $2.4-\mathrm{D}$ was used in the control treatment (no pre-treatment at $4{ }^{\circ} \mathrm{C}$ ) (Table 3). However, 'Smile' callus induction at all BAP concentrations used in combination with $2.0 \mu \mathrm{M}$ of 2,4-D was lower than the use of $2.0 \mu \mathrm{M}$ of 2,4-D alone. The oxidation recorded for 'Smile' anthers did not influence callus induction (Figures. 5A and 5B). 'Sugar Baby' had approximately 10\% anther response to callus induction when it was treated with the combination of 2,4-D $(2.0 \mu \mathrm{M})$ and BAP $(0.5 \mu \mathrm{M})$. However, this result was less in comparison to the control treatment, which only used $2.0 \mu \mathrm{M}$ of 2,4-D (Table 3). Almost all 'Sugar Baby' anthers had oxidation ranging from $61 \%$ to $90 \%$, and the response was greater to the combination of $2,4-D$ and BAP, compared to BAP alone (Figure 5C). However, these results differ from Abdollahi and coauthors, who reported a positive effect of the combination between 2,4-D and BAP on watermelon 'Charleston Gray' anthers responses to callus induction, which ranged from $75 \%$ to $88 \%$. Ashok kumar and coauthors found positive results on cucumber anthers using the same growth-regulator combinations. However, male floral bud-donor plants used in the current study were infested by the insect species Thrips tabaci, and may have entered the anther and caused tissue necrosis without apparent symptoms (data not shown), which may have ultimately influenced the results obtained. 
A

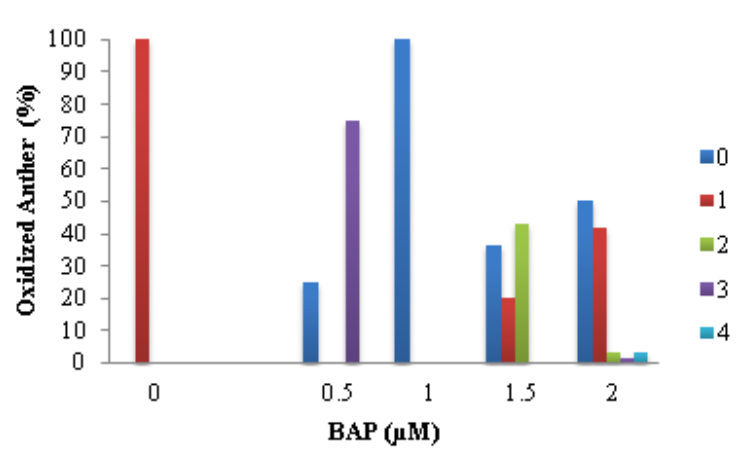

$\mathrm{C}$

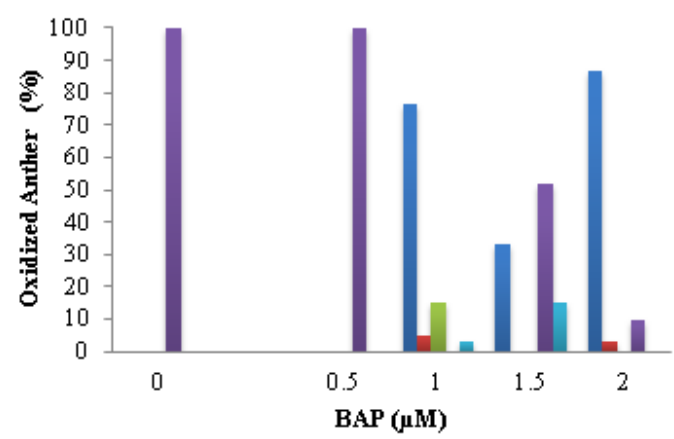

B

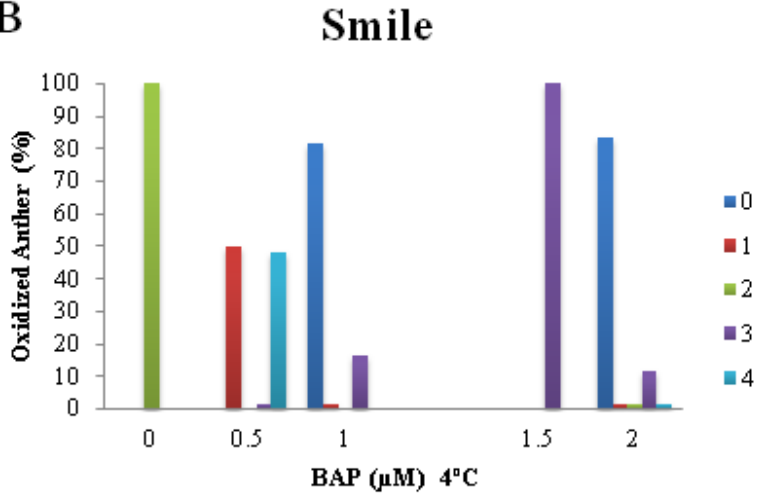

D

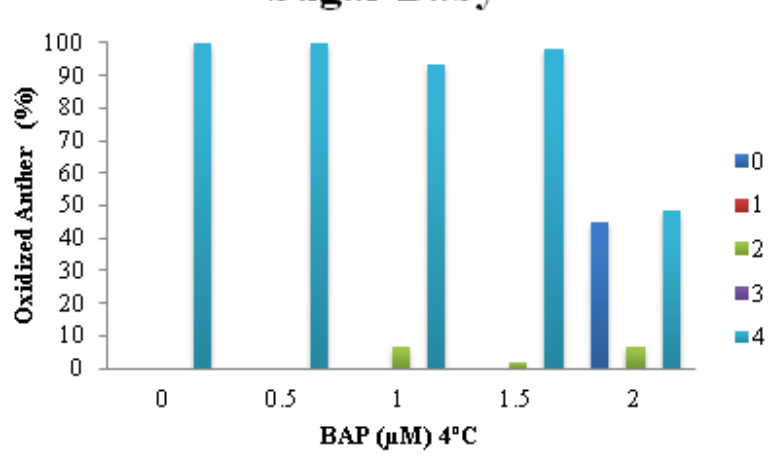

Figure 5. Anther oxidation distribution frequencies in watermelon (Citrullus lanatus) lines grown in medium containing $2.0 \mu \mathrm{M}$ of 2,4-dichlorophenoxyacetic acid (2,4-D) and different 6-benzylaminopurine (BAP) concentrations, using temperature $4^{\circ} \mathrm{C}$ as pre-treatment. Oxidized 'Smile' anthers not subjected (A) and subjected to pre-treatment (B). Oxidized 'Sugar Baby' anthers not subjected (C) and subjected to pre-treatment (D). 0) $0 \% ; 1$ ) $1-30 \%$; 2) $31-60 \%$; 3) $61-90 \%$; and 4) $91-100 \%$ of oxidized anthers.

Results indicated that anthers of the 'Smile'-deriving line had better response to callus induction when pre-treated at $4^{\circ} \mathrm{C}$ for two days than those of the 'Sugar Baby'-deriving line. The 'Smile' line had friable callus induction rate at $11.33 \%$ compared to $3.33 \%$ obtained by the 'Sugar Baby' line. The different responses to the effect of the cold pre-treatment applied to anthers may be genotype-dependent, as previously reported by Germanà (2011). 'Sugar Baby'-deriving lines (Figure 5D) had higher anther oxidation than the 'Smile'-deriving lines (Figure 5B), which may have influenced the results obtained, since phenolic oxidation affects explant development [14]. However, Ashok Kumar and coauthors and Song and coauthors found beneficial results derived from the application of low-temperature pre-treatments on cucumber anther culture. Moreover, Abdollahi and coauthors found up to $45 \%$ callogenesis rates in 'Crimson Sweet' watermelon anthers. 'Crimson Sweet' subjected to the pre-treatment at $4{ }^{\circ} \mathrm{C}$ for two days demonstrated that low temperature can positively influence the anther culture of watermelon [1].

\section{CONCLUSIONS}

It was possible to estimate pollen viability using $2 \%$ acetic carmine, and to observe the pollen grain size in the evaluated watermelon lines.

The 2,4-D growth regulator was efficient in inducing callus formation in the anthers of 'Smile' and 'Sugar Baby' watermelon.

The combination of 2,0 $\mu \mathrm{M}$ of 2,4-D and BAP did not increase the callus induction frequency in the anthers of the watermelon.

Anthers' responses to the pre-treatment at $4{ }^{\circ} \mathrm{C}$, and to the use of 2,4-D $(2.0 \mu \mathrm{M})$ in combination with BAP regulators, varied according to the watermelon genotype. 
Acknowledgments: The authors are grateful to the Coordination for the Improvement of Higher Education Personnel (CAPES - Coordenação de Aperfeiçoamento de Pessoal de Nível Superior, Finance Code 001), for granting the scholarship to CMJS; as well as to the Post-Graduation Program in Plant Genetic Resources of State University of Feira de Santana-BA and to the Brazilian Agricultural Research Corporation - Embrapa Semiárido, Petrolina, Brazil (Embrapa - Empresa Brasileira de Pesquisa Agropecuária - Embrapa Semiárido) for making their infrastructures (laboratory, field and greenhouse) available for the experiments.

Conflicts of Interest: The authors declare no conflict of interest.

\section{REFERENCES}

1. Abdollahi MR, Darbandi M, Hamidvand $Y$ et al. The influence of phytohormones, wheat ovary co-culture, and temperature stress on anther culture response of watermelon (Citrullus lanatus L.) Braz J Bot . 2015; 38:447-56. https://doi.org/10.1007/s40415-015-0152-z

2. Abu-romman S, Suwwan M, Al-ramamneh EA. The influence of plant growth regulators on callus induction from hypocotyls of cucumber (Cucumis sativus L.) Adv Environ Biol. 2013;7:339-43.

3. Ashok kumar HG, Murthy, HN, Paek KY. Embryogenesis and plant regeneration from anther cultures of Cucumis sativus L. Sci Hortic.2003;98:213-22. https://doi.org/10.1016/S0304-4238(03)00003-7

4. Baktemur G, Taşkin H, Büyükalaca S. Comparison of Different Methods for Separation of Haploid Embryo Induced through Irradiated Pollen and Their Economic Analysis in Melon (Cucumis melo var. inodorus). Scientific World J. 2013; http://dx.doi.org/10.1155/2013/529502

5. Dias RCS, Resende GM Socioeconomia. Sistema de produção de melancia. <http://sistemasdeproducao.cnptia. embrapa.br/FontesHTML/Melancia/SistemaProducaoMelancia/socioeconomia.htm>. Cited 2017 March 06

6. Faostat 2016. Food and Agriculture Organization of the United Nations. Cited 2018 Feb 19. Avalilable from: http://faostat3.fao.org/browse/Q/QC/E.\%20.

7. Gatazka J, Niemirowicz-szczytt K. Review of research on haploid production in cucumber and other cucurbits. F Horti. 2013;25:67-78. http://doi.org/10.2478/fhort-2013-0008

8. Germanà MA. Anther culture for haploid and doubled haploid production. Plant Cell Tissue Organ Cult. 2011;104:283-300. http://doi.org/10.1007/s11240-010-9852-z

9. George EF, Hall MA, Klerk G. Plant Propagation by Tissue Culture. The Netherlands: Springer; 2008.

10. Golabadi M, Ghanbari $\mathrm{Y}$, Keighobadi $\mathrm{K}$ et al. Embryo and callus induction by different factors in ovary culture of cucumber. J Appl Bot Food Qual. 2017;90:68-75. https://DOI:10.5073/JABFQ.2017.090.010

11. Guerra M, Souza MJ. Como observar cromossomos: um guia de técnicas em citogenética vegetal, animal e humana. Fundação de Pesquisa. Científica. de Ribeirão Preto, Ribeirão Preto, SP; 2002.

12. Gursoz N, Abak K, Pitrat M, Rode JC, Dumas de vaulx R. Obtention of haploid plants induced by irradiated pollen in watermelon (Citrullus lanatus). Cucurbit Genetics Coop Rep. 1991;14:109-10.

13. Martins KC, Pereira TNS, Souza SAM et al. Meiose e viabilidade polínica em acessos de Capsicum annuum e Capsicum baccatum. Cienc Rural. 2010;40:1746-51.

14. Melo B, Pinto JEBP, Luz JMQ et al Diferentes antioxidantes no controle da oxidação, germinação e desenvolvimento das plântulas na cultura in vitro de embriões da guarirobeira [Syagrus oleracea (MART.)BECC.]. Cienc Agrotec. 2001;25:1301-6.

15. Mohr, Hubert C. Watermelon Breeding. In: Basset MJ Breeding Vegetable crops. Westport: Avi, 1986.33-66.

16. Murashige T, Skoog F. A revised médium for rapid growth and bio-assay with tabacco tissue cultures. Physiol Plant. 1962; 15: 473-97. https://doi.org/10.1111/j.1399-3054.1962.tb08052.x

17. Munhoz, M, Luz CFP, Filho Meissner PE, et al. Viabilidade polínica de Caryca papaya L.: Uma comparação metodológica. Rev Bras Bot. 2008;31:209-14.

18. Munsell AH. Munsell color charts for plant tissues. Macbeth Division of Kollmorgen Instruments Corporation, Baltimore. 1977;405:1-20.

19. R Core Team. R: A language and environment for statistical computing. R Foundation for Statistical. Version 3.3.2 [software] Computing, Vienna, Austria. URL https://www.R-project.org/. 2016.

20. Riaz S, Shah AH, Malook SU et al. Study of Dichlorophenoxyacetic Acid and 6-Benzylaminopurine Effects on Callus Development in Cucurbita moschata, Mol. Plant. Breed. 2016;7:1-12. https://doi: 10.5376/mpb.2016.07.0003.

21. Santos EK, Bodanese-zanettini MH. Androgênese: Uma rota alternativa no desenvolvimento do pólen. Cienc. Rural. 2002;32:165-73. https://doi.org/10.1590/S0103-84782002000100028

22. Sari N, Rode JC, Vaulx RD Induction of Parthenogenetic Haploid Embryos after Pollination by Irradiated Pollen in Watermelon. Hortsci. 1994;29:1189-90. 
23. Shalaby TA . Factors affecting haploid induction through in vitro gynogenesis $\mathrm{n}$ summer squash (Cucurbita pepo L.) Sci Hortic. 2007;115:1-6. https://doi.org/10.1016/j.scienta.2007.07.008

24. Song H, Lou QF, Luo XD et al. Regeneration of doubled haploid plants by androgenesis of cucumber (Cucumis sativus L.) Plant Cell Tissue Organ Cult. 2007; 90:245-54. https://doi.org/10.1007/s11240-007-9263-y

25. Yetisir H, Sari N. A new method for haploid muskmelon (Cucumis melo L.) dihaploidization Sci Hortic. 2003;98:277-83. https://doi.org/10.1016/S0304-4238(02)00226-1

26. Vieira LJ, Soares TL, Rossi ML et al. Viability, production and morphology of pollen grains for different species in the genus Manihot (Euphorbiaceae). Acta Bot Bras. 2012;26:350-6. https://dx.doi.org/10.1590/S010233062012000200011.

27. Zanotto M, Brammer SP, Nascimento Junior A et al. Viabilidade polínica como seleção assistida no programa de melhoramento genético de triticale. Cienc Agrotec. 2009;33:2078-82.

28. Whitaker TW, Davis GN. Cucurbits: botany, cultivation and utilization. L. Hill, London. 1962.

(C) 2021 by the authors. Submitted for possible open access publication under the terms and conditions of the Creative Commons Attribution (CC BY NC) license (https://creativecommons.org/licenses/by-nc/4.0/). 